\title{
Trophic dynamics of eight intertidal communities of the Sylt-Rømø Bight ecosystem, northern Wadden Sea
}

\author{
Dan Baird ${ }^{1}$, Harald Asmus ${ }^{2, *}$, Ragnhild Asmus ${ }^{2}$ \\ ${ }^{1}$ Department of Zoology, Nelson Mandela Metropolitan University, PO Box 77000, Port Elizabeth, South Africa \\ ${ }^{2}$ Alfred Wegener Institute for Polar and Marine Research, Wadden Sea Station Sylt, Hafenstraße 43, 25992 List, Germany
}

\begin{abstract}
The intertidal area of the Sylt-Rømø Bight was divided into 8 benthic and 1 pelagic subsystems according to habitat nature and the unique biodiversity of each. A quantitative food web network was constructed for each of the subsystems. Each flow model consists of 56 living and 3 nonliving compartments and depicts the biomass of each, a balanced energy budget for each of the living components, and the flow of energy and material between all compartments. These models were analysed by means of network analysis that revealed a considerable amount of variability between them in terms of system properties such as total system throughput (TST), development capacity, ascendency and redundancy, and a number of dimensionless ratios used in comparative systems ecology. Mussel beds stood out as the most productive subsystem at $5095 \mathrm{mg} \mathrm{C} \mathrm{m}^{-2} \mathrm{~d}^{-1}$, with a high TST of $33571 \mathrm{mgC} \mathrm{m}^{-2} \mathrm{~d}^{-1}$. The amount of material recycled in each of the systems ranged from a high of $28 \%$ in the muddy sand flats to a low of $2.5 \%$ in the mussel beds, while the efficiency of energy transfer in the various systems fluctuated from a low of $3.3 \%$ in the sandy shoals to a high of $15 \%$ in the mussel beds. Mussel beds are highly specialized in terms of ascendancy and average mutual information in comparison with the other subsystems, but have less resilience. Most of the systems showed ratios between 0.8 and 1.4 for the 2 mutually exclusive system attributes of ascendency and redundancy. Relative redundancy indices calculated for the pelagic and mussel bed subsystems are low, indicating less organized systems with less resistance to disturbance.
\end{abstract}

KEY WORDS: Food webs $\cdot$ Network analysis $\cdot$ Spatial variability $\cdot$ Ecosystem attributes $\cdot$ Coastal ecosystems $\cdot$ German Wadden Sea

\section{INTRODUCTION}

Many studies on the structure and function of marine and coastal ecosystems based on the analysis of quantitative food webs have been published. Most of these used network analysis, a set of algorithms derived from input-output analysis, trophic and cycle analysis, and the computation of system level properties based on information theory and that reflect the complexity of organization of the system. Some of the parameters are (1) the total system throughput (or TST, which is the sum of all flows through the system and an indication of the activity of the system); (2) ascendency (or A, which is a measure of how well a system is performing and incorporates both the size and organization of flows, and is the product of TST and the average mutual information inherent in the network); (3) development capacity (or DC, which is the product of TST and the flow diversity, and is considered to be the upper limit of Ascendency); (4) system overhead (or $\theta$, which is numerically represented by the difference of $\mathrm{DC}-\mathrm{A}$, and which represents the cost to the system to operate the way it does); and (5) flow diversity (defined as DC/TST, which encompasses both the numbers and of interactions and evenness of flows in the food web network). Results from the analysis of flow networks of ecosystems provide information that can be used to approach envi- 
ronmental problems at the level of the whole ecosystem (NSF 1999, Ulanowicz 2004), and can fruitfully be used to compare ecosystems on spatial and temporal scales.

Comparisons of trophic structure and system dynamics range from studies on small spatial scales of sampling sites within a Halodule wrightii seagrass ecosystem in Florida (Baird et al. 1998) to studies of estuaries in relatively close proximity (Baird \& Ulanowicz 1993, Monaco \& Ulanowicz 1997, Scharler \& Baird 2005), to the comparison of ecosystem flow networks and system attributes on a global scale (cf. Baird et al. 1991, Christensen 1995). Intersystem comparison is complicated by the fundamental differences in the nature of the food webs, and/or by inconsistencies in the topologies of the systems (Christian et al. 2005). Several attempts, however, have been made to base intersystem comparisons of flow networks containing, for example, the same flow currency (e.g. C or N), similar degree of aggregation (i.e. number of compartments) and comparable trophic guilds (e.g. suspension feeders, benthic feeding fish, carnivorous birds) (cf. Baird et al. 1991, Christensen 1995, Monaco \& Ulanowicz 1997, Baird et al. 2004a, Scharler \& Baird 2005). Thomas \& Christian (2001) presented results derived from ecological network analysis (ENA) to assess potential changes in nitrogen cycling from nitrogen networks of 3 zones identified in each of 3 different salt marshes along the East Coast of the continental USA. The marshes were divided into different zones that reflected different communities and environmental conditions, although they were not physically separated. Few other studies have been conducted to assess system function on such small spatial scales. Network analysis, thus, provides valuable information on the fundamental functioning of an ecosystem (Wulff et al. 1989, Ulanowicz 2003, Baird et al. 2004b), while the comparison of ecosystems on spatial and temporal scales contributes to our knowledge of both basic ecology and the management of the environment (Christian et al. 2005). Patten $(1978,1985)$ and co-workers developed a slightly different approach to network analysis called 'environ analysis' to demonstrate the influence of indirect flows in a system. This approach to ecosystem analysis is reviewed by Fath \& Patten (1999). The basic theoretical concepts of ecological network analysis and its application are given by Ulanowicz (2004) and Wulff et al. (1989).

Baird et al. (2004a) provided a detailed analysis of energy flow in the Sylt-Rømø Bight, a large, shallow tidal ecosystem in the German Wadden Sea. They reported on the standing stocks and the interactions between 56 living and 3 nonliving components of the intertidal region of the system, as well as on system attributes derived from ENA. They concluded that, based on the analytical results of ENA, the Bight as a whole is a complex system whose energy pathways appear to be sensitive to perturbations. Baird et al. (2004a) and others (Asmus et al. 1998, Asmus \& Asmus 2005) pointed out that the intertidal Bight is characterized by a mosaic of spatially segregated intertidal habitats associated with different plant and animal communities, and that the biodiversity, distribution and abundance of species, and the rates of production and energy consumption of prey and predator species could vary considerably between them. The objectives of this paper are to examine the differences and similarities among these interlinked intertidal habitats at the system level.

The intertidal regions of the Bight ecosystem have been subdivided into 8 habitats, or subsystems, based on the species composition of each (Asmus \& Asmus 2005) and sediment characteristics (cf. Gätje \& Reise 1998). In this study we first constructed a quantitative food web for each of the 8 intertidal plant and animal communities as well as one for the overlying water body. Each of the flow networks illustrates the standing stocks of communities and species, energy uptake, respiration and transfers between the living and nonliving components by each component in each of the subsystems. Second, we assessed indices of functional processes (such as cycling of material and trophic efficiencies) and system level properties (such as TST, ascendency, average mutual information and flow diversity) for each of the subsystems from network analysis. Finally, we compared these results derived from network analysis among the 9 subsystems and commented on the variability in system properties between them and on their sensitivity to perturbations.

\section{MATERIALS AND METHODS}

Study area. The Sylt-Rømø Bight ( $54^{\circ} 52^{\prime}$ to $55^{\circ} 10^{\prime} \mathrm{N}$, $8^{\circ} 20^{\prime}$ to $8^{\circ} 40^{\prime} \mathrm{E}$ ) forms part of the Wadden Sea, a shallow coastal region of the North Sea stretching from the Netherlands to Denmark. The Bight is a semi-enclosed basin between the islands of Sylt, Germany, and Rømø, Denmark, and is connected to the North Sea by a $2.8 \mathrm{~km}$ wide channel (Fig. 1). The Bight has an aerial surface of $404 \mathrm{~km}^{2}$ with an intertidal area of about $135 \mathrm{~km}^{2}$. The average water temperature in the Bight varies from $5.3^{\circ} \mathrm{C}$ in winter (October to March) to $13.7^{\circ} \mathrm{C}$ in summer (April to September) and the salinity between 28 and 32. Little freshwater is discharged into the Bight so that salinity variability is mainly due to precipitation and evaporation. The average depth of the Bight is approximately $4.2 \mathrm{~m}$ at high tide, while the tidal range is on average $2 \mathrm{~m}$. The water residence time in the Bight is between 19 and $29 \mathrm{~d}$. 
Different plant and animal communities are associated with different habitat types occurring in the intertidal area of the Bight, while the remaining subtidal area of about $270 \mathrm{~km}^{2}$ consists mainly of a sandy substrate, which is rather poor in benthic macrofauna (Asmus \& Asmus 1998). The intertidal region comprises 8 habitat types, each with its own characteristic biotic community composition. These habitat types and the area they cover are given in Table 1 (cf. Asmus \& Asmus 2005), while their spatial locations are shown in Fig. 1. The various habitat types, or intertidal subsystems, are contiguous, but nevertheless separated by the nature of the substrate of each and by its characteristic species composition. The different subsystems were named according to either the dominant species (e.g. mussel beds, where the mussel, Mytilus edulis, predominates; Arenicola flats where the the lugworm, Arenicola, predominates; or $Z$. noltii beds where the dominant macrophytic species, the dwarf seagrass Zostera noltii, predominates) or to typical substrate types (e.g. mud flats, a mixture of mud and sand, sandy shoals and sandy beaches). Each subsystem differs substantially in species composition, standing stocks and productivity of the constituent species and in habitat structure so that their recognition and treatment as different subsystems of the intertidal Bight is justified.

Data base. A food web model was constructed for each of the 8 habitat and community types. In addition, the overlying water body, covering all subsystems at high tide and between which energy and material is exchanged, was treated as the 9th subsystem and named the pelagic domain. It covers an area of $135 \mathrm{~km}^{2}$, i.e. the sum of the areas of the 8 benthic subsystems with an average tidal prism $66 \times 10^{6} \mathrm{~m}^{3}$ (calculated after Backhaus et al. [1998] in Gätje \& Reise [1998]). An appropriate food web model was also constructed for this pelagic subsystem. Each model consisted of 56 living and 3 nonliving compartments and depicts the standing stock (or biomass) of each compartment, as well as the flow of energy and material between the model compartments. Not all species occurred in all of the subsystems, and neither did they occur at the same levels of abundance if they did occur in more than one habitat. To maintain the model configuration of 59 compartments throughout the analytical procedures, miniscule amounts $\left(1 \times 10^{-5} \mathrm{mg} \mathrm{C} \mathrm{m}^{-2}\right)$ were entered as biomass imports and exports for those

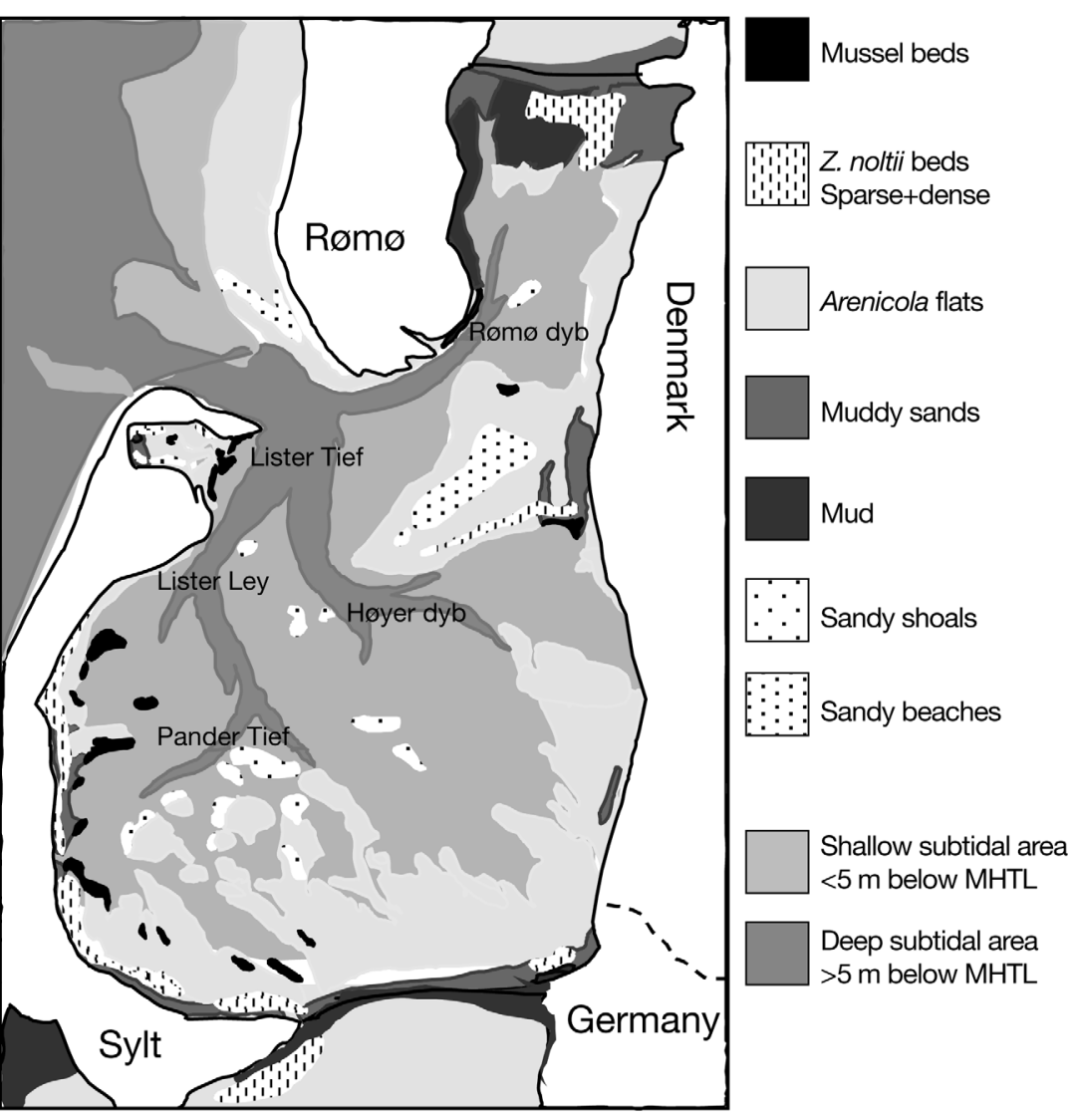

Fig. 1. The Sylt-Rømø Bight and the spatial positions and extent of the 8 intertidal subsystems. Z.noltii $=$ Zostera noltii

compartments not present in field samples from the various subsystems. These small entries had no effect on the output results of network analysis (Baird et al. 1998, 2004b). The data on community composition, standing stocks, rate of production, energy requirements and diet composition of the various compartments used in these network models were obtained from the most recent published papers and unpublished information (deposited at the Alfred Wegener Institute for Polar and Marine Research [AWI]). No stocks or rates of flow were derived from modelling, but are based on the sources cited in the text. The aerial extent, species diversity and their abundance in each of the 9 subsystems were studied over many years, and the configuration and dynamics of each of these are based upon results from these studies.

The concentrations and standing stocks of the nonliving compartments, i.e. suspended particulate organic carbon (suspended POC), dissolved organic carbon (DOC) in the water column subsystem (or the pelagic domain), and sediment particulate organic carbon (SedPOC) of all the habitats were obtained from Asmus \& Asmus (1993, 1998, 2000). Data on biomass of pelagic free living bacteria and sediment bacteria in 
Table 1. General system attributes of each of the subsystems of the Sylt-Rømø Bight

\begin{tabular}{|c|c|c|c|c|c|c|c|c|c|}
\hline \multirow[t]{2}{*}{ Attribute } & \multirow[t]{2}{*}{$\begin{array}{l}\text { Pelagic } \\
\text { domain }\end{array}$} & \multirow[t]{2}{*}{$\begin{array}{l}\text { Mussel } \\
\text { beds }\end{array}$} & \multirow[t]{2}{*}{$\begin{array}{l}\text { Arenicola } \\
\text { flats }\end{array}$} & \multicolumn{2}{|c|}{$\begin{array}{l}\text { Zostera noltii } \\
\text { beds }\end{array}$} & \multirow[t]{2}{*}{$\begin{array}{l}\text { Mud } \\
\text { flats }\end{array}$} & \multirow[t]{2}{*}{$\begin{array}{l}\text { Muddy } \\
\text { sand flats }\end{array}$} & \multirow[t]{2}{*}{$\begin{array}{l}\text { Sandy } \\
\text { shoals }\end{array}$} & \multirow[t]{2}{*}{$\begin{array}{c}\text { Sandy } \\
\text { beaches }\end{array}$} \\
\hline & & & & Sparse & Dense & & & & \\
\hline $\begin{array}{l}\text { Habitat area }\left(\mathrm{km}^{2}\right) \\
(\% \text { of total area in parentheses })\end{array}$ & 135 & $\begin{array}{c}0.36 \\
(0.27)\end{array}$ & $\begin{array}{l}90.99 \\
(67.4)\end{array}$ & $\begin{array}{c}4.76 \\
(7.89)\end{array}$ & 10.77 & 3.85 & 13.25 & 3.7 & 7.32 \\
\hline $\begin{array}{l}\text { (\% of total area in parentheses) } \\
\text { Total biomass }\left(\mathrm{mg} \mathrm{C} \mathrm{m}^{-2}\right)\end{array}$ & $\begin{array}{c}(100) \\
1061.0\end{array}$ & $\begin{array}{c}(0.27) \\
954798.9\end{array}$ & $\begin{array}{c}(67.4) \\
28606.3\end{array}$ & $\begin{array}{c}(7.89) \\
52654.1\end{array}$ & $\begin{array}{c}(3.25) \\
65631.9\end{array}$ & $\begin{array}{c}(2.85) \\
23285.0\end{array}$ & $\begin{array}{c}(9.81) \\
40937.3\end{array}$ & $\begin{array}{c}(2.74) \\
9564.3\end{array}$ & $\begin{array}{l}(5.42) \\
7222.3\end{array}$ \\
\hline $\begin{array}{l}\text { Total biomass autotrophs } \\
\left(\mathrm{mg} \mathrm{C} \mathrm{m}^{-2}\right)\end{array}$ & 1040.0 & 146366.0 & 130.0 & 14160.0 & 31010.0 & 120.0 & 130.0 & 130.0 & 270.0 \\
\hline $\begin{array}{l}\text { Net primary production } \\
\left(\mathrm{NPP}, \mathrm{mg} \mathrm{C} \mathrm{m}^{-2} \mathrm{~d}^{-1}\right)\end{array}$ & 247.3 & 3998.2 & 647.6 & 757.8 & 1007.6 & 635.2 & 635.2 & 647.7 & 588.7 \\
\hline $\begin{array}{l}\text { Total biomass heterothrophs } \\
\left(\mathrm{mg} \mathrm{C} \mathrm{m}^{-2}\right)\end{array}$ & 21.0 & 808432.9 & 28476.3 & 38581.0 & 34708.9 & 23165.0 & 40807.3 & 9434.3 & 6952.3 \\
\hline $\begin{array}{l}\text { Total heterotrophic production } \\
\left(\mathrm{mg} \mathrm{C} \mathrm{m}^{-2} \mathrm{~d}^{-1}\right)\end{array}$ & 77.6 & 1097.6 & 271.1 & 279.9 & 514.9 & 355.1 & 539.4 & 186.7 & 130.3 \\
\hline $\begin{array}{l}\text { Total subsystem production } \\
\left(\mathrm{mg} \mathrm{C} \mathrm{m}^{-2} \mathrm{~d}^{-1}\right)\end{array}$ & 324.9 & 5095.8 & 918.7 & 1037.7 & 1522.5 & 990.3 & 1174.6 & 834.4 & 719.0 \\
\hline $\begin{array}{l}\text { Percent production of intertidal } \\
\text { subsystems per } \mathrm{m}^{2}\end{array}$ & & 41.5 & 7.5 & 8.4 & 12.4 & 8.1 & 9.6 & 6.8 & 5.8 \\
\hline $\begin{array}{l}\text { Total subsystem production } \\
\text { per area (tC) }\end{array}$ & 43.9 & 1.8 & 83.6 & 4.9 & 13.9 & 3.4 & 12.5 & 3.0 & 5.3 \\
\hline $\begin{array}{l}\text { Percent production of intertidal } \\
\text { subsystems per area }\end{array}$ & & 1.4 & 65.1 & 3.8 & 10.8 & 2.6 & 9.7 & 2.3 & 4.1 \\
\hline $\mathrm{P} / \mathrm{B} \mathrm{d}^{-1}$ of subsystem & 0.306 & 0.005 & 0.032 & 0.020 & 0.023 & 0.043 & 0.020 & 0.080 & 0.100 \\
\hline NPP efficiency (\%) & 26.9 & 16.9 & 22.3 & 85.0 & 42.1 & 65.0 & 66.9 & 11.7 & 13.9 \\
\hline
\end{tabular}

all the subsystems were obtained from Kirchman et al. (1986) and Rusch et al. (2001). The biomass, rates of gross primary production (GPP) and net primary production (NPP) of the 3 primary producer communities, namely phytoplankton, microphytobenthos and macrophytes (Zostera noltii and Fucus vesiculosus) as they occur in the different subsystems are given by Asmus \& Bauerfeind (1994) and in Gätje \& Reise (1998). Average annual biomass estimates for the various macrofaunal and fish species and communities were extracted from the published literature (cf. Asmus 1987, 1994, Asmus \& Asmus 1990, 1993, 1998, 2005, Gätje \& Reise 1998) and from unpublished information $(\mathrm{H}$. Asmus unpupl. data). Bird numbers were obtained from Scheiffarth \& Nehls (1997) and their feeding behaviour and energy uptake in the various habitats from Nehls et al. (1997), Scheiffarth (2001) and Scheiffarth et al. (2002).

Network construction. Input data required for network analysis requires information on the standing stock of each compartment and flows between the compartments within the ecosystem, as well as external inputs to and exports from it. The flow network, or food web, of each subsystem consisted of 56 living and 3 nonliving compartments respectively (the living compartments are sequentially numbered from 1 to 56 , and the nonliving ones from 57 to 59 (see Appendix 1: MEPS Electronic Supplement at www.int-res.com/ journals/suppl/m351p025_app1.pdf). Biomass of the compartments are given in $\mathrm{mgC}^{-2}$ and export, imports and flows between them in $\mathrm{mg} \mathrm{C} \mathrm{m}^{-2} \mathrm{~d}^{-1}$.
Each living compartment identified in each of the subsystems was balanced in terms of energy uptake and energy dissipation (or respiration), growth and egestion. For the 3 primary producer compartments (phytoplankton, microphytobenthos and macroalgae) GPP was assumed equal to NPP and respiration. The values of GPP for the various primary producers were considered as energy inputs into the subsystems. Exudation by aquatic plants is considered to be an important source of DOC in aquatic ecosystems (Valiela 1995). Vegter \& de Visscher (1984) and Valiela (1995) reported that about $25 \%$ of the net photosynthate of phytoplankton was released as DOC to the water column, and about $2 \%$ for macroalgae and seagrasses (Sieburth \& Jensen 1969, Brylinsksy 1977, Kirchman et al. 1986, Valiela 1995). Exuded DOC from macrophyte beds was considered as input to the pelagic subsystem where it was utilized by free living bacteria, whilst the excess was exported to the rest of the Bight.

Energy budgets were constructed for each of the heterotrophic compartments according to the balanced energy equation where energy uptake (or consumption, C) equals respiration (R), egesta (E), and secondary production (P). Rates of consumption, respiration and production were obtained from the literature or calculated using appropriate ecological efficiencies such as $\mathrm{P} / \mathrm{B}, \mathrm{P} / \mathrm{C}, \mathrm{R} / \mathrm{B}$ and $\mathrm{P} / \mathrm{R}$ ratios where $\mathrm{B}=$ biomass. The determination and literature sources of the energetics of most of the plant and animal species (or communities such as zooplankton) occurring in the Bight are given in detail by Baird et al. (2004a). 
Diet composition for each component was derived from the synthesis of published literature and local expert knowledge (Ehlert 1964, Jacobsen 1967, Fenchel \& Koefoed 1976, de Vlas 1979, Fauchald \& Jumars 1979, Jensen \& Siegismund 1980, Heip et al. 1984, Pihl \& Rosenberg 1984, Pihl 1985, Zwarts \& Blomert 1992, Baird et al. 2004a, Asmus \& Asmus 2005, and sources in Gätje \& Reise 1998). The diet compositions of the individual species that occur in the various subsystems were compiled by H. Asmus (unpubl. data) and based on published literature and unpublished data residing at the AWI in List, Sylt, Germany.

Each of the subsystems was assumed to represent a steady-state condition in the sense that the inputs (GPP, or consumption $\mathrm{C}$ ) in each of the living components of the networks were balanced by corresponding outputs (i.e. respiration and NPP for autotrophs, and E + R + P for heterotrophs). This assumption implies that the ecosystem as a whole also occurs in a steady state and assumes the underlying principle of the conservation of mass, namely that total inputs are balanced by total outputs. The mass-balancing of trophic networks, however, has its limitations and weaknesses (Menge 1995, Baird et al. 2004b), and we present results from network analysis based on non-steady states in 6 of the 9 subsystems. The reasons for these non-equilibrium networks are based on first where predator demand exceeds prey production. We assumed in such cases that predators will feed off the remaining biomass or switch to other prey, and we, thus, did not 'import' additional prey biomass to balance those specific living compartments namely \#7, 19, 24 and 27 in the mussel beds, and \#6 in the mudflat subsystem. Second, nonliving compartments, specifically sediment POC, can at times result in large imbalances between sediment POC inputs and its utilization. Excess sediment POC, which normally consists of benthic egestion and mortality (or excess production) and non-utilized dead plants, is usually exported from a system to balance the in situ production of this material. We retained benthic egestion and organismal mortality, i.e. as sediment POC, within the systems based on observation and ecological sense. Thus, we did not attempt to balance the Sediment POC compartments in all of the subsystems, with the exception of the sandy shoals and sandy beach subsystems, where water movements are known to remove excess material (Asmus \& Asmus 1998). However, imports of, for example, phytoplankton from the pelagic domain to other subsystems, such as the mussel bed subsystem, as food for suspension feeders were unavoidable, but reflect the true ecological situation.

Excess production and egestion by water column organisms (bacteria, zooplankton) were assumed to remain in suspension as POC. Egesta of benthic invertebrates, fish and birds, and all unused production of the benthos, were assumed to become sediment POC, which was considered as the energy source for benthic bacteria. Bird production and excess fish production was exported from the various subsystems. Excess Fucus vesiculosus production on the mussel bed was also exported, as it has been observed to occur regularly. This material eventually ends up on the sandy beaches from where it is either buried in the supratidal fringe or is again exported out of the bight by tidal currents. Shortfalls in phytoplankton and suspended POC were imported from the adjacent Wadden Sea where the production and concentration of these components are respectively higher than over the intertidal benthic subsystems.

The data required for network analysis to be performed were prepared in the recommended scientific Committee for Oceanographic Research (SCOR) format. The 9 data files each contain the average annual standing stock or biomass of each of the 59 compartments, imports to and exports from each compartment where applicable, respiration values for each of the living components, and quantified flows between the compartments in each subsystem.

Compartments are numbered in the text preceded by \#. These input data files are available in Appendix 2 at: www.int-res.com/journals/suppl/m351p025_app2/.

Network analysis. Network analysis routines were used to assess the structure and function of the 9 subsystems of the Sylt-Rømø Bight. The methodology of network analysis is described in detail by Wulff et al. (1989), while Ulanowicz (2004) reviewed the quantitative methods used in ecological network analysis (ENA), which consists essentially of methods for the systematic assessment of ecological flow networks and computes various functional indices and system properties of natural ecosystems. The software package NETWRK 4.2a (Ulanowicz \& Kay 1991) was used to perform the analyses and a broad overview of the kind of analyses executed by this package is briefly described below.

1. The Lindeman Trophic Analysis transforms each complex network of trophic web into a linear food chain with discrete integer trophic levels, i.e. the Lindeman Spine (Ulanowicz 1986). The Lindeman Spine shows the amount of carbon, or energy, each trophic level receives from the preceding one as well as the amount leaving each level through respiration, export, returns to the detrital pool and the net production passed on to the next higher trophic level. The apportionment of species or trophic guilds to discrete trophic levels is described in Ulanowicz \& Kemp (1979) and Ulanowicz (2004). Primary producers and detritus together form the first trophic level, and all herbivorous feeding and the use of nonliving detritus forms the second level. The Lindeman Spine allows the calculation of the 
efficiency of energy transfer from one level to the next, as well as the trophic efficiency computed as the logarithmic mean of the entire system over all integer trophic levels (Baird \& Ulanowicz 1989).

2. The biogeochemical routine of NETWRK4.2a assesses the structure and magnitude of cycling within the system. Results from this analysis yields the Finn Cycling Index (FCI), which represents the fraction of flow in a system that is recycled (Finn 1976). The FCI is derived from the ratio Tc/TST, where TST equals the total system throughput (i.e. the sum of all flows in the system) and Tc the amount devoted to cycling. The FCI is a measure of the retentiveness of a system (Baird et al. 2004b); the higher the FCI, the greater the proportion of TST recycled. This routine also describes the structure of biogeochemical cycling through the identification and enumeration of all internal cycles in the network. The cycle distribution displays the amount of energy that flows through cycles of various lengths, i.e. the series of transfers between compartments beginning and ending in the same compartment without going through any compartment twice.

3. The average path length (APL) is a system descriptor that measures the average number of compartments that a unit of carbon passes through from its entry into the system before it leaves it. The APL is defined by (TST-Z)/Z, where TST is the total system throughput (see 5) and where $Z$ equals the sum of all exogenous inputs (Finn 1976, Baird et al. 1991). The average path length is expected to be higher in systems with high degrees of flow diversity and cycling (Christensen 1995, Thomas \& Christian 2001).

4. The average residence time (ART) of energy in the system is the ratio between the total system biomass and the sum of all outputs (respiration and exports) (Christensen 1995). It is a measure of the time elapsed between a unit of energy entering the system and leaving it again.

5. Various global system indices, based on information theory, describe the developmental and organizational state of the ecosystem (Ulanowicz 1986, 2004). The TST measures the extent of the total activity of the system, and is calculated as the sum of all the flows through all compartments. The TST can be considered as a surrogate for the total power generated within the system (Baird et al. 1998). The system ascendency (A), which is a single measure of the magnitude and diversity of flows between compartments, thus reflects on the functional attributes of the system. It incorporates both the size and organization of flows into a single index, and is formally expressed as the product of TST and the average mutual information (AMI) inherent in the flow network (Morris et al. 2005). The AMI index, or normalized ascendency, is indicative of the developmental status of the ecosystem and, thus, of its inherent organization, i.e. the degree of specialization of flows in the network (Ulanowicz 2004). Complex trophic structure and high system productivity enhance ascendency. The development capacity (DC) measures the potential for a system to develop and is the natural upper limit of A. The total system overheads (i.e. overheads on imports, exports and dissipation) and redundancy (i.e. a measure of the uncertainty associated with the presence of multiple or parallel pathways among the components of the network [Ulanowicz \& Norden 1990]) are numerically represented by the difference of $\mathrm{DC}-\mathrm{A}$, and represents that fraction of the $\mathrm{DC}$ that does not appear to be as organized structure (Bondini $\&$ Bondavalli 2002). The magnitudes of the imports and exports reflect the self-reliance of a system, i.e. the higher these values, the more dependent the system becomes on external exchanges. A system with low redundancy is considered to be susceptible to external perturbations, which may affect the trophic interactions between system components. Parallel pathways of energy and material transfers on the other hand, however, can act as a buffer or reserve should external perturbations occur and in changes in biodiversity. It is postulated that a sustainable system requires a balance between ascendency and redundancy. Should a perturbation occur, the system can draw from the overhead to keep it in operation, but in a less organized state (Baird et al. 1991, Scharler \& Baird 2005).

Ascendency measures the efficiency and definitiveness by which energy transfers are made, whereas the overhead quantifies how inefficient and ambiguous the system performs on average. Higher indices of A reflect increased ecological succession characterized by, for example, species richness, decreased cost of overheads to the system, greater internalisation of resources and finer trophic specialisation (Ulanowicz \& Abarca-Arenas 1997, Scharler \& Baird 2005).

Internal ascendency $\left(\mathrm{A}_{\mathrm{i}}\right)$ and internal developmental capacity $\left(D_{\mathrm{i}}\right)$ are functions of internal exchanges alone and, thus, exclude exogenous transfers.

The ratios $A / C$ and $A_{i} / D C_{i}$ have been used to compare the organizational status of ecosystems on temporal (Baird \& Ulanowicz 1989, Baird \& Heymans 1996, Baird et al. 1998, 2004b) and spatial (Baird et al. 1991, 2004a, Baird \& Ulanowicz 1993, Baird 1999) scales. The magnitude of various attributes, particularly the DC, A, overheads and redundancy, are strongly influenced by the total activity, or TST (cf. Ulanowicz 2004). By dividing theses capacities (DC, A and overheads) by $\mathrm{TST}$, the resultant normalized values, given in Table 2, are scaled to eliminate the singular effect of TST (cf. Baird \& Ulanowicz 1989, Baird et al. 1998). 
Flow diversity, defined as DC/TST (or normalized DC), measures both the number of interactions and the evenness of flows in the food web, and is thus a much more dynamic concept than species diversity (Baird et al. 1998). Comparatively higher values of this index indicate an increase in interactions and a lower degree of unevenness and variability in the flow structure (Baird et al. 2004b). The effective number of connec-

Table 2. Global system attributes derived from network analysis for each subsystem of the Sylt-Rømø Bight. Values reflect results from network models where excess production and sediment POC were not exported from the subsystems with the exception of the Pelagic, Sandy Shoals and Sandy Beach subsystems. In compartments where predation exceeds production, no artificial imports were made to balance the compartment

\begin{tabular}{|c|c|c|c|c|c|c|c|c|c|}
\hline \multirow[t]{2}{*}{ Sytstem attributes } & \multirow[t]{2}{*}{$\begin{array}{l}\text { Pelagic } \\
\text { domain }\end{array}$} & \multirow[t]{2}{*}{$\begin{array}{l}\text { Mussel } \\
\text { beds }\end{array}$} & \multirow[t]{2}{*}{$\begin{array}{l}\text { Arenicola } \\
\text { flats }\end{array}$} & \multicolumn{2}{|c|}{$\begin{array}{c}\text { Zostera noltii } \\
\end{array}$} & \multirow[t]{2}{*}{$\begin{array}{l}\text { Mud } \\
\text { flats }\end{array}$} & \multirow[t]{2}{*}{$\begin{array}{l}\text { Muddy sand } \\
\text { flats }\end{array}$} & \multirow[t]{2}{*}{$\begin{array}{l}\text { Sandy } \\
\text { shoals }\end{array}$} & \multirow[t]{2}{*}{$\begin{array}{l}\text { Sandy } \\
\text { beaches }\end{array}$} \\
\hline & & & & Sparse & Dense & & & & \\
\hline $\begin{array}{l}\text { Trophic efficiency } \\
\text { (logarithmic mean, \%) }\end{array}$ & $<1$ & 14.92 & 3.47 & 5.06 & 5.58 & 6.13 & 7.31 & 3.3 & 6.5 \\
\hline Detritivory $\left(\mathrm{mg} \mathrm{C} \mathrm{m}^{-2} \mathrm{~d}^{-1}\right)$ & 152.2 & 1523 & 550 & 645 & 1084 & 812 & 1050 & 406 & 656 \\
\hline Detritivory:herbivory ratio (D:H) & $33: 1$ & $0.3: 1$ & $0.9: 1$ & $0.8: 1$ & $1.5: 1$ & $1.2: 1$ & $1.5: 1$ & $2.7: 1$ & $4.7: 1$ \\
\hline Number of cycles & 0 & 173 & 202 & 113 & 195 & 158 & 342 & 87 & 92 \\
\hline Finn cycling index (\%) & 0 & 2.53 & 20.3 & 22.62 & 24.76 & 25.89 & 27.53 & 16.2 & 16.16 \\
\hline $\begin{array}{l}\text { Average path length } \\
(\mathrm{APL}=\mathrm{TST}-\mathrm{Z} / \mathrm{Z})\end{array}$ & 1.43 & 1.94 & 2.24 & 2.74 & 2.48 & 3.13 & 3.29 & 2.46 & 2.68 \\
\hline $\begin{array}{l}\text { Average Residence Time } \\
\text { (ART, d) (Sum Biomass/Sum } \\
\text { Exports + Respiration) }\end{array}$ & 2.01 & 83.73 & 48.06 & 55.52 & 46.54 & 22.62 & 37.36 & 8.85 & 7.47 \\
\hline $\begin{array}{l}\text { Total system throughput } \\
\left(\mathrm{TST}, \mathrm{mg} \mathrm{C} \mathrm{m}^{-2} \mathrm{~d}^{-1}\right)\end{array}$ & 1282 & 33571 & 4928 & 5639 & 7566 & 5248 & 5852 & 3739 & 3556 \\
\hline $\begin{array}{l}\text { Total system throughput } \\
\left(\mathrm{TST}, \mathrm{tC} \text { area }^{-1} \mathrm{~d}^{-1}\right)\end{array}$ & 173 & 12.1 & 448.4 & 26.8 & 81.5 & 20.2 & 77.5 & 13.8 & 26.0 \\
\hline $\begin{array}{l}\text { Development capacity } \\
\left(\mathrm{mgC} \mathrm{m}^{-2} \mathrm{~d}^{-1} \text { bits }\right)\end{array}$ & 3588 & 135620 & 21275 & 26124 & 35539 & 24936 & 28506 & 14043 & 12775 \\
\hline Ascendency (mg C m${ }^{-2} \mathrm{~d}^{-1}$ bits) & 1717 & 67521 & 8508 & 10331 & 13027 & 8714 & 10216 & 6281 & 5633 \\
\hline Relative ascendancy (A/DC, \%) & 47.9 & 49.8 & 40.0 & 39.5 & 36.7 & 34.9 & 35.8 & 44.7 & 44.1 \\
\hline $\begin{array}{l}\text { Average mutual information } \\
\text { (A/TST) (normalized A) }\end{array}$ & 1.34 & 2.01 & 1.73 & 1.83 & 1.72 & 1.66 & 1.75 & 1.68 & 1.58 \\
\hline $\begin{array}{l}\text { Average internal mutual } \\
\text { information }\left(\mathrm{A}_{\mathrm{i}} / \mathrm{TST}\right)\end{array}$ & 0.41 & 0.91 & 1.01 & 1.12 & 0.96 & 0.94 & 1.05 & 0.69 & 0.73 \\
\hline $\begin{array}{l}\text { Overheads on imports } \\
\text { (mg C m }{ }^{-2} \mathrm{~d}^{-1} \text { bits) }\end{array}$ & 416 & 17781 & 1758 & 2152 & 3440 & 1200 & 1561 & 505 & 384 \\
\hline $\begin{array}{l}\text { Overheads on exports } \\
\left(\mathrm{mgC} \mathrm{m}^{-2} \mathrm{~d}^{-1} \text { bits }\right)\end{array}$ & 601 & 2690 & 2.2 & 11.7 & 12.4 & 15 & 1.5 & 421 & 366 \\
\hline $\begin{array}{l}\text { Dissipative overheads } \\
\left.\text { (mgC m-2 } \mathrm{d}^{-1} \text { bits }\right)\end{array}$ & 532 & 23590 & 2783 & 4175 & 5744 & 4277 & 4824 & 1911 & 248 \\
\hline $\begin{array}{l}\text { Redundancy } \\
\left(\mathrm{mg} \mathrm{C} \mathrm{m}^{-2} \mathrm{~d}^{-1} \mathrm{bits}\right)\end{array}$ & 321 & 24034 & 8224 & 9454 & 13315 & 10730 & 11904 & 4926 & 3914 \\
\hline Relative redundancy (R/DC, \%) & 8.9 & 17.7 & 38.7 & 34.5 & 37.5 & 43.0 & 41.8 & 35.1 & 30.6 \\
\hline $\begin{array}{l}\text { Normalized redundancy } \\
\text { (R/TST) }\end{array}$ & 0.25 & 0.72 & 1.67 & 1.68 & 1.76 & 2.04 & 2.03 & 1.32 & 1.10 \\
\hline $\begin{array}{l}\text { Internal development capacity } \\
\left(\mathrm{mg} \mathrm{C} \mathrm{m}^{-2} \mathrm{~d}^{-1} \text { bits }\right)\end{array}$ & 844 & 54659 & 13269 & 15898 & 20830 & 15843 & 18145 & 7512 & 6508 \\
\hline $\begin{array}{l}\text { Internal ascendency } \\
\left(\mathrm{mg} \mathrm{C} \mathrm{m}^{-2} \mathrm{~d}^{-1} \text { bits }\right)\end{array}$ & 522 & 30624 & 5046 & 6444 & 7515 & 5113 & 6241 & 2586 & 2594 \\
\hline $\begin{array}{l}\text { Relative internal ascendency } \\
(\mathrm{Ai} / \mathrm{DCi}, \%)\end{array}$ & 61.9 & 56.0 & 38.0 & 40.5 & 36.1 & 32.3 & 34.4 & 34.4 & 39.9 \\
\hline $\begin{array}{l}\text { Internal redundancy } \\
\left(\mathrm{mg} \mathrm{C} \mathrm{m}^{-2} \mathrm{~d}^{-1} \text { bits }\right)\end{array}$ & 321 & 24034 & 8224 & 9454 & 13315 & 10730 & 11904 & 4926 & 3914 \\
\hline $\begin{array}{l}\text { Relative internal redundancy } \\
(\mathrm{Ri} / \mathrm{DCi}, \%)\end{array}$ & 38.1 & 44.0 & 62.0 & 59.5 & 63.9 & 67.7 & 65.6 & 65.6 & 60.1 \\
\hline $\begin{array}{l}\text { Flow diversity DC } \\
\text { (DC/TST, \%) (normalized DC) }\end{array}$ & 2.8 & 4.04 & 4.32 & 4.63 & 4.70 & 4.75 & 4.87 & 3.76 & 3.59 \\
\hline$\Phi($ sum of overheads/TST) & 1.46 & 2.23 & 2.42 & 2.68 & 2.92 & 3.20 & 3.14 & 2.08 & 1.38 \\
\hline Overall connectance & 1.58 & 1.55 & 2.08 & 2.14 & 2.19 & 2.46 & 2.43 & 1.99 & 1.87 \\
\hline $\begin{array}{l}\text { Intercompartmental } \\
\text { connectance }\end{array}$ & 1.05 & 1.78 & 2.60 & 2.50 & 2.80 & 3.10 & 2.99 & 2.31 & 1.87 \\
\hline $\begin{array}{l}\text { Foodweb connectance } \\
\text { (living compartments only) }\end{array}$ & 1.00 & 1.29 & 1.85 & 1.83 & 2.01 & 2.40 & 2.52 & 1.8 & 2.2 \\
\hline GPP/TST & 0.34 & 0.16 & 0.20 & 0.23 & 0.24 & 019 & 017 & 0.27 & 025 \\
\hline
\end{tabular}


tions between compartments is given by 3 connectance indices, and is derived from the log-averaged number of links calculated from the systems overhead (Baird et al. 2004b). The overall connectance includes the effect of external transfers; the internal connectance index characterizes only internal exchanges, whereas the food web connectance index refers only to transfers among the living compartments in the system.

Network analysis was performed on each of the 9 subsystems in 2 ways. First, analyses were done on 'non-steady state' flow models. That is, in those subsystems where some compartments were not balanced for the reasons given previously (see 'Network construction'). Second, all models were mass-balanced, and the differences in the resultant output values of system properties between balanced and unbalanced flow models are briefly referred to in the Results.

The software routine (NETWRK 4.2a) that performs all the above mentioned analyses and its supporting documentation may be downloaded from www.cbl. umces.edu/ ulan/ntwk/network.html. By importing the data files of Appendix 2 into NETWRK4.2a, the output results from these analyses can be generated.

\section{RESULTS}

As mentioned in previous sections ('Network construction' and 'Network analysis') excess production and egesta were not exported as sediment POC from the subsystems, with the exception of the pelagic domain, sandy shoals and sandy beach subsystems, while some compartments in some of the subsystems were not balanced where predation exceeded production. Since this approach is, in our opinion, a true reflection of the ecological and physical processes in the Bight, the results from the unbalanced models will be the focus of discussion in this paper. We nevertheless briefly refer to the differences between ENA output results of balanced and unbalanced flow models. The results from ENA are presented under 3 headings, namely trophic structure, cycling and system level properties, and the discussion restricted to those indices most often cited in the literature (cf. Christian et al. 2005). An illustrated, generalized, aggregated flow model of the Bight showing the main energy flow pathways among a number of trophic guilds is presented in Baird et al. (2004a).

\section{Trophic structure}

The flow models of the 9 subsystems of the SyltRømø Bight comprise different species assemblages, different biomass or stock size of species (or of trophic assemblages) in each, energy requirements of the living components, production estimates, and quantified predator-prey interactions. Annually averaged estimates of the amount of energy consumed, rates of respiration, production and egestion by heterothrophs, and of the NPP and respiration of autotrophs of each subsystem, are provided in Appendix 1. This table gives information on the composition of the communities associated with each habitat type, the biomass and energetics of the living components in each, as well as the trophic position of each compartment or species in the food web. A number of system characteristics are given in Table 1, which shows, inter alia, the total biomass of the living components in each subsystem, the production rate per $\mathrm{m}^{2}$ per day and weighted production per area, the daily P/B ratio, and the net primary production (NPP) efficiency (i.e. the percent of net autotrophic production consumed by herbivores).

It appears that the total standing stock of autotrophs and heterotrophs of the mussel beds is greater than in any of the other subsystems and yields $41.5 \%$ of the production of all the intertidal subsystems on a per $\mathrm{m}^{2}$ basis at daily production rate of $5.1 \mathrm{~g} \mathrm{C} \mathrm{m}^{-2}$ (see Table 1). High production during summer of the macroalga Fucus vesiculosus accounts for the high biomass $(15 \%)$ and productivity (77\%) of the mussel beds. However, the biomass and productivity of macrofauna and the presence of large numbers of birds feeding on the mussel beds contribute substantially to the biomass and productivity of this subsystem. Heterotrophic biomass and production are also higher here than in any of the other subsystems at $808.4 \mathrm{gC} \mathrm{m}^{-2}$ and $1.1 \mathrm{gC}$ $\mathrm{m}^{-2} \mathrm{~d}^{-1}$, respectively (see Table 1). Birds (eider duck, oyster catcher and herring gull) are particularly active predators on the blue mussel Mytilus edulis (\#19), the bivalve Macoma balthica (\#24), and the shore crab Carcinus maenas (\#27), so that the production of these prey species does not, on average, satisfy predator demand. Their production rates were exceeded by predation by about 910,93 , and $55 \mathrm{mgC} \mathrm{m}^{-2} \mathrm{~d}^{-1}$, respectively. High consumption rates of birds have been reported by Schheiffarth \& Nehls (1997), who commented that average prey production in the mussel banks cannot satisfy bird energy demands. It is assumed that bird predators will use the existing prey biomass that will be replenished by recruitment and growth during subsequent seasons. Predation on Littorina littorea (\#7) particularly by the shore crab exceeded its production by about $13 \mathrm{mgC} \mathrm{m}^{-2} \mathrm{~d}^{-1}$.

Only about $5 \%$ of the Fucus vesiculosus production is directly consumed and although benthic microalgae are heavily grazed by various herbivores, the NPP efficiency of $16.9 \%$ of the mussel beds is low in comparison with most of the other subsystems (Table 1). Most 
of the unused $F$. vesiculosus does not remain on the mussel beds, but is washed ashore, degraded to detritus or exported from the Bight by tidal currents.

The high abundance and energy demands of Littorina Littorea (\#7), Gammarus spp. (\#18), Macoma balthica (\#24) and small crustaceans (\#26) on the mussel beds resulted in the overexploitation of the production of microphytobenthos (\#2) by about $400 \mathrm{mgC} \mathrm{m}^{-2}$ $\mathrm{d}^{-1}$ by these consumers. In this instance it was assumed that mobile epibenthos (such as L. littorea and Gammarus spp.) would feed on benthic microalgae additionally at sand flats adjacent to the mussel beds, as observed by H. Asmus (pers. obs.), and their energy uptake on adjacent areas were considered as an input into the mussel bed subsystem. In all other compartments of the various subsystems predation did not exceed production, with the exception of Hydrobia ulvae (\#6) on the mud flats that was over utilized by $58.4 \mathrm{mg} \mathrm{C} \mathrm{m}^{-2} \mathrm{~d}^{-1}$, mainly by the shelduck (\#38). This compartment was also not balanced to compensate for the shortfall in production.

Net phytoplankton production in the Bight was reported at $247 \mathrm{mgC} \mathrm{m}^{-2} \mathrm{~d}^{-1}$ (Baird et al. 2004a), whilst the sum of phytoplankton consumption by suspension feeders on all of the subsystems considering the area covered approximates $387 \mathrm{mgC} \mathrm{m}^{-2} \mathrm{~d}^{-1}$. This shortfall of $140 \mathrm{mgC} \mathrm{m}^{-2} \mathrm{~d}^{-1}$ was compensated partly by the import of phytoplankton biomass from the coastal waters of the North Sea where phytoplankton biomass during the period of data recording was on average about $70 \mathrm{mgC} \mathrm{m}^{-3}$ (Franke et al. 2004, Wiltshire \& Manly 2004 ) and partly by that of the subtidal water of the entire Wadden Sea where phytoplankton standing

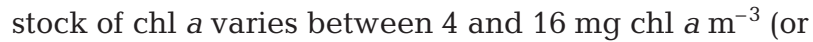
between 200 and 800 phytoplankton carbon $\mathrm{m}^{-3}$ (Rick et al. 2006). The shortfall of phytoplankton carbon of $140 \mathrm{mgC} \mathrm{m}^{-2} \mathrm{~d}^{-1}$ for all subsystems is almost of the same magnitude as that estimated for the total Bight at $160 \mathrm{mgC} \mathrm{m}^{-2} \mathrm{~d}^{-1}$ by Baird et al. (2004a). Suspension feeders furthermore consume approximately about $58 \mathrm{mgC} \mathrm{m}{ }^{-2} \mathrm{~d}^{-1}$ of suspended POC (\#57), which was also imported to the intertidal regions by tidal currents from the North Sea and the deeper parts of Wadden Sea where suspended POC occurs at concentrations of between 0.5 and $6 \mathrm{~g} \mathrm{~m}^{-3}$ (Cadee 1982, Hickel 1984). A twice daily tidal turnover rate of $66 \times 10^{6} \mathrm{~m}^{3}$ and the fact that between 8 and $12 \%$ of the Bight's water is exchanged per tidal cycle with the North Sea (Fast et al. 1999) ensures the sufficient supply of phytoplankton and suspended POC to consumers of the intertidal subsystems.

The daily P/B ratios and TST are both considered as indices of the functional and trophic activities of ecosystems (Baird et al. 1991, Christensen 1995). With the exception of the pelagic subsystem, the daily P/B ratios lie between a high of 0.1 for the sandy beaches and a low of 0.005 for the mussel beds. The higher ratio for the pelagic subsystem is entirely due to the high turnover rates of phytoplankton and free living bacteria, while the lower $\mathrm{P} / \mathrm{B}$ ratio of the mussel beds can be ascribed to the high biomass but low productivity of long-lived species. The TST values of the intertidal systems show an inverse relationship with the P/B ratios. The highest TST value and lowest daily P/B ratio (see Tables $1 \& 2$ ) were observed for the mussel beds (33571 $\mathrm{mg} \mathrm{C} \mathrm{m}^{-2} \mathrm{~d}^{-1}$ and $0.005 \mathrm{~d}^{-1}$, respectively), with the lowest TST ( $3556 \mathrm{mg} \mathrm{C} \mathrm{m}^{-2} \mathrm{~d}^{-1}$ ) calculated for the sandy beach subsystem having the highest P/B ratio of $0.1 \mathrm{~d}^{-1}$. The high rates of productivity of Fucus vesiculosus and predation activity of invertebrate and vertebrate predators are largely responsible for the high TST of the mussel beds. The throughput through the macrophytes compartment (\#3) alone accounted for about $16 \%$ of the TST of this subsystem. Mussel beds contribute $41.5 \%$ to the daily production on a per $\mathrm{m}^{2}$ basis of all 8 benthic intertidal subsystems (see Table 1), and are, thus, areas of high activity (high TST) and of intense predation by birds.

Table 3. Cycle distribution of the 9 subsystems showing the amount of carbon cycling through loops of various path lengths expressed as a fraction (\%) of the total ammount cycled in each in $\mathrm{mg} \mathrm{C} \mathrm{m}^{-2} \mathrm{~d}^{-1}$ (no cycles were identified in the pelagic domain)

\begin{tabular}{|c|c|c|c|c|c|c|c|c|c|}
\hline \multirow[t]{2}{*}{ Path length } & \multirow[t]{2}{*}{$\begin{array}{l}\text { Pelagic } \\
\text { domain }\end{array}$} & \multirow[t]{2}{*}{$\begin{array}{c}\text { Mussel } \\
\text { beds }\end{array}$} & \multirow[t]{2}{*}{$\begin{array}{l}\text { Arenicola } \\
\text { flats }\end{array}$} & \multicolumn{2}{|c|}{$\begin{array}{c}\text { Zostera noltii } \\
\text { beds }\end{array}$} & \multirow[t]{2}{*}{$\begin{array}{l}\text { Mud } \\
\text { flats }\end{array}$} & \multirow[t]{2}{*}{$\begin{array}{l}\text { Muddy sand } \\
\text { flats }\end{array}$} & \multirow[t]{2}{*}{$\begin{array}{l}\text { Sandy } \\
\text { shoals }\end{array}$} & \multirow[t]{2}{*}{$\begin{array}{c}\text { Sandy } \\
\text { beaches }\end{array}$} \\
\hline & & & & Sparse & Dense & & & & \\
\hline \multicolumn{10}{|l|}{1} \\
\hline 2 & 0 & 40.15 & 50.97 & 59.44 & 48.48 & 40.06 & 50.23 & 60.22 & 87.06 \\
\hline 3 & 0 & 48.79 & 48.57 & 39.84 & 51.15 & 55.97 & 47.75 & 37.55 & 11.79 \\
\hline 4 & 0 & 9.41 & 0.44 & 0.71 & 0.35 & 3.96 & 1.94 & 2.22 & 1.14 \\
\hline 5 & 0 & 1.66 & 0.01 & 0.01 & 0.01 & 0.01 & 0.08 & 0.02 & 0.01 \\
\hline 6 & 0 & & 0.01 & & 0.00003 & & 0.001 & 0.0001 & 0.000073 \\
\hline 7 & 0 & & & & & & 0.0001 & & \\
\hline $\begin{array}{l}\text { Total amount cycled/ } \\
\text { system }\left(\mathrm{mg} \mathrm{C} \mathrm{m}^{-2} \mathrm{~d}^{-1}\right)\end{array}$ & 0 & 856.80 & 1000.51 & 1275.16 & 1872.79 & 1357.87 & 1610.48 & 604.51 & 573.17 \\
\hline
\end{tabular}


Two other indices that also reflect on the trophic functions of ecosystems are the average path length (APL) and the average residence time (ART). The APLs of the various subsystems are given in Table 2 and range from 1.43 in the pelagic domain to 3.29 in the muddy sand flat habitat. This means that most energy is used over fewer steps in the water column than in the other intertidal systems (see Table 2). The average APL calculated for all subsystems is $2.5(\mathrm{SD}=0.57$, $\mathrm{n}=9$ ), which is close to the value of 2.6 reported for the whole Bight by Baird et al. (2004a).

Material and energy appear to reside for a much longer time $(\mathrm{ART}=84 \mathrm{~d})$ in the mussel beds than in any of the other subsystems. The organic material deposited into the mussel beds, as reported by Albrecht \& Reise (1994), contributes to the long ART calculated for this subsystem. This material is only removed during strong storms, especially those from easterly directions (Asmus \& Asmus 1998). The ART in the other benthic systems fluctuates widely from $56 \mathrm{~d}$ in the sparse Zostera noltii beds to $7.5 \mathrm{~d}$ in the sandy beaches. The ARTs in the sparse and dense $Z$. noltii beds are 55.5 and $46.5 \mathrm{~d}$ respectively, $48 \mathrm{~d}$ in the Arenicola flats, $37 \mathrm{~d}$ in the muddy sand system and $23 \mathrm{~d}$ in the mud flats. Material appears to reside for much shorter time periods in the sandy shoals (9 d) and sandy beaches ( $7 \mathrm{~d}$ ) (see Table 2). The ART of energy is particularly short in the pelagic domain, which is clearly a function of the short inundation time of the intertidal habitats. The ART calculation is based on the ratio between biomass and the sum of exports and respiration of a system. Where larger differences exist between these attributes, the residence time would be longer. The comparable high $\mathrm{P} / \mathrm{B}$ ratios of the pelagic and sandy beach subsystems are also indicators of the rapid turnover of energy there before it leaves those systems.

The carbon flow networks of each subsystem were transferred into the simplified Lindeman Spines and illustrated in Fig. 2. The first trophic level consists of primary producers and detritus combined, but these are illustrated separately to show the relevant amounts of grazing (herbivory) and detritivory, respectively, from the first to the second trophic level. Returns from each trophic level, as well as imports into the detrital pool, GPP (as an energy input into Level I), respiration and exports from each are shown in Fig. 2. The efficiency by which energy and material is transferred from one level to the next are given as a percent value in box of the Spine. In the pelagic domain about $30 \%$ of the input to the first level is utilized in this subsystem, but little of phytoplankton is utilized at the second level because of low zooplankton standing stocks and grazing rates (see Fig. 2), which results in a very low efficiency $(<1 \%)$ at the second trophic level. Excess phytoplank- ton and bacteria are given as exports from the first and second trophic levels in Fig. 2. Excess Fucus vesiculosus and bacterial production is exported from the first and second levels, respectively, of the mussel beds (see Fig. 2), while the rather large exports from Levels III and IV are due to bird predation. The higher trophic efficiency seen at Level IV compared with that at the previous level shows the ability of the mussel beds to transfer energy to higher trophic levels. The same observation can be made for the Arenicola flat, Zostera noltii beds, and muddy sand flats. This is due to better efficiencies of higher level predators, such as birds and fishes, compared with predators on lower levels, such as Nephthys, shore crabs and shrimps, which may cause a bottleneck for the energy flow in these communities. In the other communities the efficiency of transfer between the trophic levels shows a continuous decrease from lower to higher trophic levels.

The logarithmic mean of the trophic efficiencies of the pelagic domain is the lowest $(<1 \%)$ and the highest $(15 \%)$ in the mussel bed subsystem (see Table 2$)$. The mean trophic efficiencies of the other subsystems vary within a narrow range of between 3.3 and $7.3 \%$, and fall within the range of efficiencies reported for a seagrass bed ecosystem with a comparable number of compartments (51) in Florida, USA (Baird et al. 1998). The number of trophic levels range from 3 in the pelagic to 6 in Arenicola flats, dense Zostera noltii beds, muddy sand flats and sandy shoal subsystems.

\section{Structure and magnitude of cycling}

The cycling of energy and material is an inherent and universal process in all natural ecosystems that contribute to their autonomous behaviour (Ulanowicz 1986). Cycling occurs through a number of cycles of different path lengths. First, we enumerate the number of cycles, second, the amount of material cycled through loops of various path lengths, and third, the amount recycled in each of the 9 subsystems.

The number of cycles per subsystem varies from zero in the pelagic domain to 342 in the muddy sand flat subsystem (see Table 2). The occurrence of few cycles appears to be typical of pelagic systems. The cycle distribution in Table 3 shows how much material (expressed as a percentage of the total flow) flows through cycles of various lengths in each subsystem. In most systems, with the exception of the mussel beds, more than $95 \%$ of the cycled material takes place via cycles containing 2 and 3 compartments, with small amounts cycled through loops involving 4 or more compartments. These short cycles invariably involve the sediment bacteria (\#55), meiobenthos (\#56) and sediment POC (\#58) compartments and include species using 
sediment POC and sediment bacteria as partial food resources. Short pathways are also indicative of fast rates of cycling (Baird \& Ulanowicz 1993) as opposed to systems where cycling occurs over longer pathways (Baird et al. 1991). In the mussel beds, however, about $11 \%$ of cycling takes place over longer pathways involving 4 to 6 compartments because of the heavy predation of top predators (birds in compartments \#35 to 40 and 47 to 50) on prey at lower trophic positions such as Gammarus spp. (\#18), Mytilus edulis (\#19), Macoma balthica (\#24) and Carcinus maenas (\#27). The sediment bacteria and sediment POC compartments are virtually always involved in these longer cycles, and in which invertebrate species compartments such as the Oligochaeta (\#11) and the shore crab (\#27), and vertebrates such as Atlantic cod Gadus morhua (\#36), Муохоcephalus scorpio, eider duck Somateria mollissima (\#39), black-headed gull Larus ridibundus (\#47) and other birds (\#50) frequently participate. The involvement of fish and invertebrates is clearly through their egesta, retained in the mussel beds as sediment POC, which is subsequently used by invertebrates and which are in turn subjected to vertebrate predation.

The amount of material cycled in each subsystem, given in Table 3, is expressed as a fraction of the TST in the Finn Cycling Index (FCI) given in Table 2. The FCI and the APL follow the same trend in the benthic systems, with the highest FCI and APL occurring in the muddy sand flat subsystem and the lowest FCI and APL in the mussel beds. High APLs are usually associated with high degrees of flow diversity and cycling, which is clearly evident from Table 2. Little material is recycled in the mussel beds because of the high TST, which is ascribed to the high Fucus vesiculosus production, little utilization of it and its subsequent export from this subsystem. Cycling indices calculated for the sandy shoals and sandy beach subsystems are low and appear to be typical for these kinds of exposed habitats. For example, Heymans \& McLachlan (1996) reported an APL of 2.3 and a FCI of $13 \%$ for a sandy beach system in South Africa.

\section{System level properties}

Global measures of system organization, such as the TST, development capacity (DC), ascendency (A), redundancy $(\mathrm{R})$, average mutual information (AMI), flow diversity and connectance indices were derived from network analysis and are listed in Table 2 for each of the 9 subsystems. Although the actual numerical values derived for DC, A, Overheads, and R are of interest, dimensionless ratios of relative ascendency (A/DC), relative internal ascendency $\left(\mathrm{A}_{\mathrm{i}} / \mathrm{DC}_{\mathrm{i}}\right)$, AMI, relative redundancy $(\mathrm{R} / \mathrm{DC})$, relative internal redun- dancy $\left(\mathrm{R}_{\mathrm{i}} / \mathrm{DC}_{\mathrm{i}}\right)$ and flow diversity are considered to be suitable indices for intersystem comparison (Wulff et al. 1989, Baird et al. 1991, Christian et al. 2005) and have been used extensively in the literature for system comparisons over spatial and temporal scales. No tests of statistical significance between the values of the indices derived from ENA were conducted due to the complexity of comparing information-theoretic combinations (Monaco \& Ulanowicz 1997, Patricio et al. (2004), while the NETWRK4 software does not readily allow access to sensitivity or uncertainty analysis (Baird et al. 2004b). Also, due to the logarithmic nature of these indices (i.e. TST, DC, A and R) and their derivatives (e.g. AMI, A/C ratios, flow diversity and connectance indices), small numerical differences can represent large differences in ecosystem structure and organization (Patricio et al. 2004). The relative ascendancy (A/DC ratio) of the mussel bed is the highest of all the systems at about $50 \%$, indicating an apparently well organized system. The lowest A/DC ratio is found in the mud flats $(35 \%)$. The wide range illustrates different states of organization in the various subsystems of the Bight. The internal relative $A_{i} / D C_{i}$ ratios are functions of internal exchanges only. They show an increase compared with the A/DC ratio in some subsystems (pelagic by $14 \%$, mussel beds by $6.2 \%$, and sparse Zostera noltii by $1 \%$ ), whereas the other subsystems show a consistent decrease, with the percent change ranging from $2 \%$ (Arenicola flats) to $10.3 \%$ in the sandy shoals system (see Table 2). A decrease in this ratio would indicate some degree of dependence of these subsystems on exogenous connections with adjacent systems (Baird et al. 1991), which indeed reflects the dependence of most of the Bight's subsystems on imports from the overlying pelagic domain. The high in situ production of Fucus vesiculosus, which uses internally produced nutrients for growth (Asmus \& Asmus 1998), could explain the increase in the $\mathrm{Ai} / \mathrm{Ci}$ ratio in the mussel beds, The high A/DC ratios also point to a relatively high degree of internal self-organization. The A/DC ratio is highest in mussel beds followed by the pelagic domain and the sandy shoals and sandy beaches. The increase in the $A_{i} / D C_{i}$ ratio (based on internal exchanges only) versus the $\mathrm{A} / \mathrm{DC}$ ratio by $14 \%$ in the pelagic system can be ascribed to the removal of all external imports, namely energy for GPP and DOC inputs from macrophyte exudation. Once these are removed, the internal exchanges are limited to a simple grazing chain involving phytoplankton, zooplankton and herring Clupea harengus, and of bacteria absorbing DOC, reflecting a simple system but a relatively well organized one. A similar argument can be made for the mussel bed system, namely the removal of external energy to sustain the high $F$. vesiculosus production. 
Pelagic domain
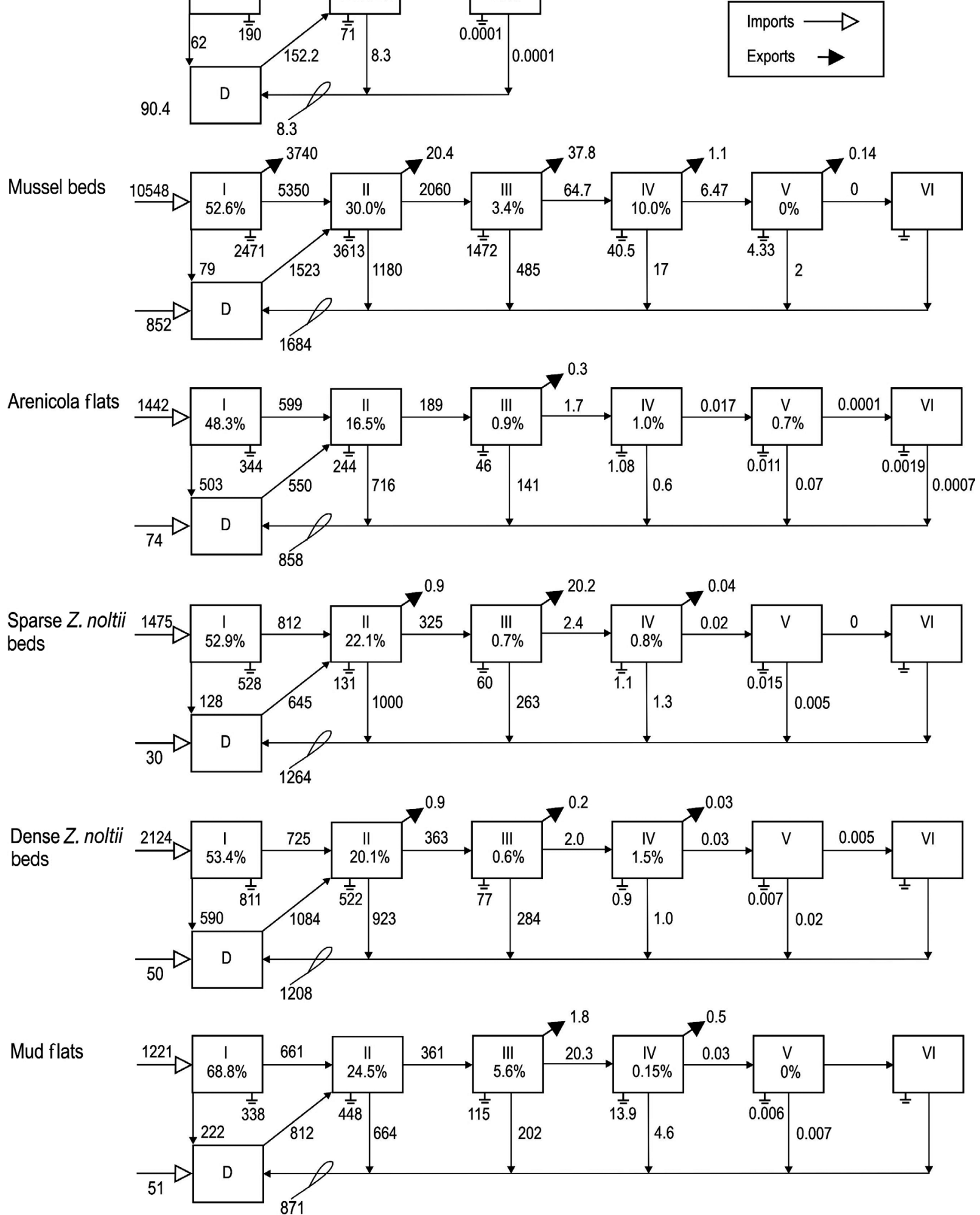

Fig. 2. Lindeman Spines of the 9 subsystems of the Sylt-Rømø Bight. The boxes indicated D refer to the detrital pool in each subsystem, and the Roman numerals in the boxes of the Spine to discrete trophic levels. Percent values in Spine boxes refer to the efficiency of energy transfer between the integer trophic levels. Z. noltii = Zostera noltii 

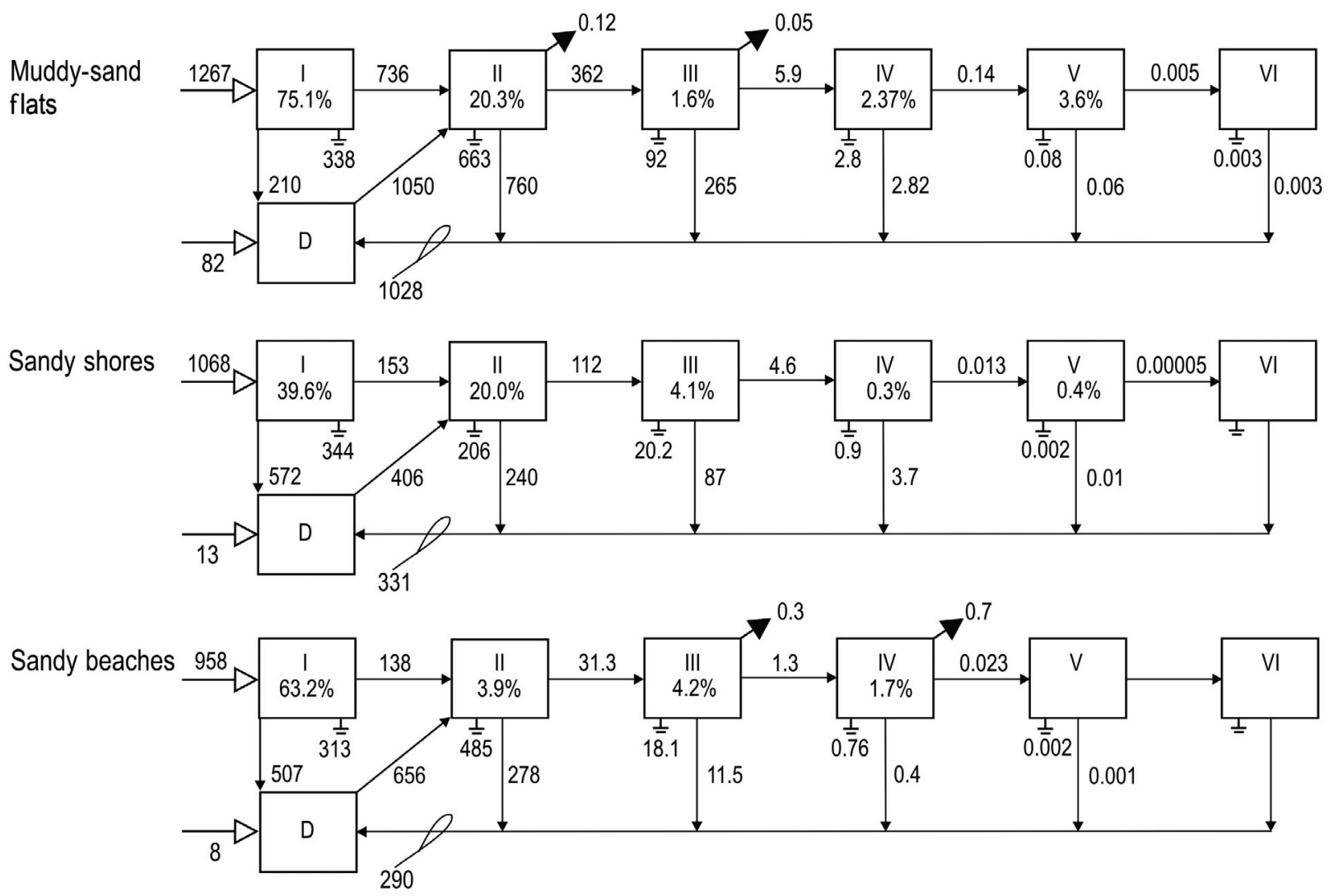

Fig. 2 (continued)

The AMI, or normalized ascendency, values (indices indicative of the level of inherent organization and of the degree of specialization) are highest in the mussel bed subsystem at 2.01 (Table 2). This index varies between 1.34 and 1.83 in the other systems (see Table 2). Fucus vesiculosus appears to play a prominent role in the mussel bed dynamics. It increases the TST as well as A through the magnitude of flows, i.e. the import of energy for $F$. vesiculosus production, the large quantity of exudates (DOC) and the export of large amounts of unused plant material. However, F. vesiculosus does not contribute much to the flow structure of the mussel beds, since only a few species $(\# 18,26)$ feed on it, which is reflected in the lower flow diversity and connectance indices (see Table 2). The high TST of the mussel beds are mainly due to $F$. vesiculosus and the high $\mathrm{A} / \mathrm{C}$ and $\mathrm{Ai} / \mathrm{DC}$ ratios, and high AMI value ratios can, thus, be ascribed to an inflated ascendency, which is enhanced by high system activity due to the size of the flows associated with $F$. vesiculosus and does not necessesarily point to a well organized system. If the GPP of all subsystems is normalized by dividing it by the TST, these values range from 0.16 in mussel beds to 0.27 in sandy shoals (see Table 2); the low ratio in the mussel bed again points to the prominent influence of $F$. vesiculosus in this subsystem once its high system throughput is removed.
The flow diversity indices (which measure both the number of interactions and the evenness of flows in the subsystems) are the lowest in the pelagic domain (2.8) and intermediate in the sandy shoals and sandy beaches (3.76 and 3.59, respectively) compared with the other subsystem values which range from 4.04 in the mussel bed to 4.87 in the muddy sand flat (see Table 2).

The relative redundancy, relative internal redundancy and the normalized redundancy ratios, considered to be measures of system stability (Rutledge et al. 1976, Christensen 1995, Baird et al. 1998), are given in Table 2 . The relative redundancy ratios vary from $18 \%$ for the mussel beds to a high of $43 \%$ in the mud flats, implying a reduction in parallel trophic pathways from the mud flats to the mussel beds and, thus, a reduction in relative stability in terms of redundancy (Scharler \& Baird 2005). The mussel bed and pelagic subsystem (redundancy ratio of $9 \%$ ) with low relative redundancy ratios, therefore, exhibit less stability than the other subsystems. The normalized redundancy values, where the effect of TST is removed, show the same trend, namely lower values for the pelagic (0.25) and mussel bed (0.7) subsystems, and higher values for the others with the highest (2.0) exhibited by the mud and muddy sand flats. However, when internal exchanges 
only are considered, the relative internal redundancy of the mussel beds increase dramatically to $44 \%$, showing greater internal stability in the absence of external imports and exports. This ration fluctuates at much higher levels (between 59 and $67 \%$ in the other subsystems).

Another set of flow networks were constructed in which all model compartments in all of the subsystems were balanced by importing or exporting shortages and excesses, respectively, but without affecting the biomasses or flows. This did not change the structure of the network in any way nor the conclusions. The shortfall in the unbalanced compartments in the mussel beds (\#7, 19, 24 and 27) and mudflats (\#6) constituted only 0.1 and $0.25 \%$ of the heterotrophic standing stocks in the 2 subsystems, respectively. Of interest is that the relative internal ascendency $(\mathrm{Ai} / \mathrm{Ci})$ ratios of the unbalanced networks are larger than in the balanced ones, probably due to the lesser dependence of the unbalanced systems on external exchanges and, thus, with higher internal organization. The same trends occurs when the internal AMI (Ai/TST) is calculated for each subsystem; the differences between the balanced and unbalanced models show a consistent increase in the levels of organization and degree of specialization in the unbalanced food web networks.

The differences in system attributes, whether small or large, were consistent for any particular attribute for all systems. It appears that the system level properties do not differ dramatically between the balanced and unbalanced models. The unbalanced models, however, are, in our opinion, ecologically justifiable and that network analysis of these flow models are based on sound empirical observations.

\section{DISCUSSION}

In this study we compared flow networks of intertidal subsystems of the Sylt-Rømø Bight using network analysis. These subsystems were identified by the nature of the habitat and biodiversity. However, the same species may occur in different habitats, since they are contiguous and not separated by physical barriers, but occur at different levels of abundance, biomass and production rates as shown, for example, by Polte et al. (2005) for commonly occurring species such as the shore crab (\#27), the brown shrimp Crangon crangon \#28), and 2 gobiid fish species (\#30 \& 31). We acknowledge the possibility of inter-habitat exchanges by mobile epifauna and, thus, the transfer of energy between habitats. We argue, however, that for the purpose of assessing the trophic function and system level properties for each of the habitats, the treatment of each as a subsystem of the whole is justified based on empirical data of species distribution and abundance, habitat preference of benthic invertebrates and feeding behaviour of vertebrates (cf. Asmus \& Asmus 2005, Polte et al. 2005). The pelagic subsystem can be considered as the domain from which energy can be imported and to which excess production and material can be exported. For example, suspension feeders obtain food from the water column (such as phytoplankton, free living bacteria and suspended POC), which has been considered as having being imported from the pelagic subsystem. Community characteristics in terms of species composition and abundance are given in Appendix 1, while diet composition and rates of exchange between the various components of each system are given in Appendix 2.

Ecological network analysis allows a valuable approach to compare the ecological function of ecosystems and provides numerous system level indices (listed in Table 2) that can be used in this context. These indices are obviously influenced by the interplay of various physical and chemical forcings, such as temperature fluctuations over months (Baird et al. 1998) or seasons (Baird \& Ulanowicz 1989, Gaedke \& Straile 1994), nitrogen concentrations over days (Field et al. 1989), nutrient loading and hypoxia over seasons (Baird et al. 2004b), or the magnitude of freshwater inflows in estuaries (Scharler \& Baird 2005). Ecosystems can, thus, be assessed on temporal and spatial scales from the suite of ENA system level outputs. Obviously, seasonal differences in temperature, for example, will affect these outputs on temporal scales. We have used annual averages in the biomass, production rates and energy requirements of the various components, and the ENA results can be considered to be derived under similar environmental conditions for all of the subsystems and, thus, comparable. Furthermore, the derivation of system indices by ENA is also a function of the biodiversity of an ecosystem since biodiversity is linked to many ecosystem processes (Ieno et al. 2006). Changes in species diversity will affect ecosystem function (Bulling et al. 2006), and the detailed analyses of the constituent subsystems of the Bight presented here provide a basis against which future changes in biodiversity and their effects can be measured at the ecosystem level.

The comparison of whole system indices reveals interesting similarities and differences between the 8 intertidal benthic subsystems in the Bight. Greater cycling was assumed to be indicative of system maturity. Here the FCI of the mussel beds $(2.53 \%)$ is low compared with the relative ascendency of $49.8 \%$, whereas this relationship (between the FCI and the $\mathrm{A} / \mathrm{C}$ ratios) is much smaller for the other intertidal subsystems. There also appears to be in general an inverse relationship between the FCI and the relative ascen- 
dancy (A/C) (cf. Baird et al. 1991) and the larger this relationship is, the less organized and more stressed a system could be. The inverse relationship between the FCI and relative ascendency is evident for all systems, but appears to be the highest in the mussel beds and the lowest in the muddy sand flats.

High APL and flow diversity values have been associated with high degrees of interactions and diversity in terms of flows within the system, and these can also be viewed in conjunction with the connectance indices and the normalized ascendency ratio (or the AMI). The highest values for all of these were derived for the mussel beds, Arenicola flats, dense and sparse Zostera noltii beds, and mud and muddy sand flats (see Table 2). Values of these indices fluctuate within narrow ranges, which are consistently higher than the values of the same indices computed for the pelagic, sandy shoals and sandy beach subsystems. From these observations it would appear that the benthic subsystems can roughly be grouped into 2 groups. The first group consists of the mussel bed, Arenicola flats, dense and sparse $Z$. noltii beds, and mud and muddy sand flats, all of which show high degrees of interactions, evenness of flows and low degrees of variability in interactions and flows when compared with the second group of sandy shoals and sandy beaches.

The magnitude of redundancy is often referenced to the susceptibility of a system to perturbations and, thus, its stability. High redundancy signifies that the system is maintaining a high number of parallel trophic pathways by which energy or material passes between any 2 arbitrary components in the system (Ulanowicz 2004). Should a perturbation occur, the system then has the capacity to use the remaining pathways to function the way it does. The relative and normalized redundancy indices (R/DC and $\mathrm{R} / \mathrm{TST}$, respectively) are lower in the mussel beds (see Table 2) indicating fewer parallel pathways exist here than in any of the other benthic subsystems. The mussel beds are indeed heavily exploited by a number of bird species (including the eider duck, oystercatcher Haematopus ostralegus, 3 gull species and an assortment of other bird predators (\#50) feeding essentially on Mytilus edulis. A perturbation that would cause a dramatic decrease in the productivity of prey species on the mussel beds will inevitably affect the bird populations adversely in one way or another. In view of the existence of strong links between many predators and few prey species (i.e. few alternative or parallel pathways) this system can be considered to posses less stability when faced with external perturbations. The redundancy indices for the other subsystems are relatively high, reflecting multiple parallel pathways and, thus, more resistance to external perturbations.
It has been hypothesized that biodiversity is linked with ecosystem functioning (Duffy \& Stachowicz 2006) from which it follows that biodiversity could affect ecosystem stability. We have illustrated that the diversity in pathways, given by the redundancy index, is associated with system stability. A change in biodiversity will affect the connectedness by causing either a reduction or an increase in the number of parallel pathways (or the redundancy) and, thus, the stability of the ecosystem. In our investigation a high redundancy was estimated for those communities that show a relatively high diversity such as mussel beds and dense Zostera noltii beds. Although species richness is high in those communities, single species dominate the biomass of the community and, hence, regulate trophic flows as well as community structure. Therefore, it can be expected that system stability does not depend only on species diversity but also on species evenness.

In conclusion, this study on the dynamics of several intertidal benthic habitats and their associated biotic communities illustrated the differences and similarities between subsystems within the greater Bight. It clearly illustrated the high TST of the mussel bed subsystem and high values for both the ascendency (A) and relative ascendency (A/DC). The high ascendency is derived from a very high TST, and Ulanowicz (2003) postulated that ascendency could be high in a system because of a resource that has caused an 'explosion' in TST. Ulanowicz (2003) further argued that too much activity (i.e. a high TST) could jeopardize the internal stability of a system, which would be reflected in systems with low AMI among their flows. It can be argued that although the high Fucus vesiculosus production inflates TST and A, the resultant comparably high AMI and flow diversity values do not necessarily indicate an organized system. Ulanowicz (2003) also suggested that the larger the overhead $\Phi$ (i.e. the sum of the overheads on imports, exports, respiration and redundancy) in a system, the greater the resistance, and, thus, the stability of a system to counter the effects of a disturbance. The overhead $\Phi$, when scaled by TST, is the lowest in the sandy beach and sandy shoal systems (1.38 and 2.08, respectively) and range at slightly higher values between 2.23 and 3.2 in the other benthic subsystems (see Table 2). Of these the mussel bed has the lowest index at 2.23 and is, together with the sandy shoal and sandy beach systems, more vulnerable to external and internal perturbations. The variability in system properties between the different subsystems suggests that the sustainability of the whole Bight system appears to be dependent on the efficient functioning of its constituent subsystems.

Acknowledgements. This study was supported by the Alfred Wegener Institute for Polar and Marine Research (AWI). D.B. thanks the AWI in particular and also the National 
Research Foundation of South Africa for their support during the course of this study. This publication is closely related to the EU-network of MARBEF, and thus is registered as a MARBEF publication under MPS-7057.

\section{LITERATURE CITED}

Albrecht AS, Reise K (1994) Effects of Fucus vesiculosus covering intertidal mussel beds in the Wadden Sea. Helgol Meeresunters 48:243-256

Asmus H (1987) Secondary production of an intertidal mussel bed community related to its storage and turnover compartments. Mar Ecol Prog Ser 39:251-266

Asmus H (1994) Benthic grazers and suspension feeders: Which one assumes the energetic dominance in Königshafen? Helgol Meeresunters 48:217-231

Asmus H, Asmus R (1990) Trophic relationships in the tidal flat areas: To what extent are tidal flats dependent on imported food? Neth J Sea Res 27:93-99

Asmus H, Asmus RM (1993) Phytoplankton-mussel bed interactions in intertidal ecosystems. In: Dame RF (ed) Bivalve filter feeders in estuarine and coastal ecosystem processes. NATO ASI Series G33, Springer-Verlag, Berlin, p 57-84

Asmus H, Asmus R (1998) The role of macrobenthic communities for sediment-water material exchange in the Sylt-Rømø tidal basin. Senckenb Marit 29:111-119

Asmus H, Asmus R (2000) Material exchange and food web of seagrass beds in the Sylt-Rømø Bight: How significant are community changes at the ecosystem level? Helgol Mar Res 54:137-150

Asmus H, Asmus R (2005) Significance of suspension-feeder systems on different spatial scales. In: Dame RF, Olenin S (eds) The comparative roles of suspension-feeders in ecosystems. Springer, Berlin, p 199-219

Asmus H, Lackschewitz D, Asmus R, Scheiffarth G, Nehls G, Herrmann JP (1998) Carbon flow in the food web of tidal flats of the Sylt-Rømø Wadden Sea. In: Gätje C, Reise K (eds) The Wadden Sea ecosystem: exchange, transport, and transformation processes. Springer, Berlin, p 393-420

Asmus RM, Bauerfeind E (1994) The microphytobenthos of Königshafen-spatial and seasonal distribution on a sandy tidal flat. Helgol Wiss Meeresunters 48:257-276

Backhaus J, Hartke D, Hübner U, Lohse H, Müller A (1998) Hydrography and climate of the List Tidal Basin. In: Gätje C, Reise K (eds) The Wadden Sea ecosystem: exchange, transport and transformation processes. Springer, Berlin, p 39-54

Baird D (1999) Estuaries as ecosystems: a functional and comparative analysis. In: Allanson BR, Baird D (eds) Estuaries of South Africa. Cambridge University Press, Cambridge, p 269-288

Baird D, Heymans JJ (1996) Assessment of ecosystem changes in response to freshwater inflow of the Kromme River estuary, St. Francis Bay, South Africa: a network analysis approach. Water SA 22:307-318

Baird D, Ulanowicz RE (1989) The seasonal dynamics of the Chesapeake Bay ecosystem. Ecol Monogr 59(4):329-364

Baird D, Ulanowicz RE (1993) Comparative study on the trophic structure, cycling and ecosystem properties of four tidal estuaries. Mar Ecol Prog Ser 99:221-237

Baird D, McGlade JM, Ulanowicz RE (1991) The comparative ecology of six marine ecosystems. Philos Trans R Soc Lond B Biol Sci 333:15-29

Baird D, Luzckovich J, Christian RR (1998) Assessment of spatial and temporal variability in ecosystem properties of the St Marks National Wildlife Refuge, Apalachee Bay, Florida. Estuar Coast Shelf Sci 47:329-349

Baird D, Asmus H, Asmus R (2004a) Energy flow of a boreal intertidal ecosystem, the Sylt-Rømø Bight. Mar Ecol Prog Ser 279:45-61

Baird D, Christian RR, Petersen C, Johnson G (2004b) Consequences of hypoxia on estuarine ecosystem function: energy diversion from consumers to microbes. Ecol Appl 14:805-822

Bondini A, Bondavalli C (2002) Towards a sustainable use of water resources: a whole-ecosystem approach using network analysis. Intl J Environ Pollut 18:463-485

Brylinski M (1977) Release of dissolved organic matter by some marine macrophytes. Mar Biol 39:213-220

Bulling MT, White PCL, Raffaelli D, Pierce GJ (2006) Using model systems to address the biodiversity-ecosystem functioning process. Mar Ecol Prog Ser 311:295-309

Cadee GC (1982) Tidal and seasonal variation in particulate and dissolved organic carbon in the western Dutch Wadden Sea and the Marsdiep tidal inlet. Neth J Sea Res 15:228-249

Christensen V (1995) Ecosystem maturity - towards unification. Ecol Model 77:3-32

Christian RR, Baird D, Luczkovich J, Johnson JC, Scharler UM, Ulanowicz RE (2005) Role of network analysis in comparative ecosystem ecology of estuaries. In: Belgrano A, Scharler UM, Dunne J, Ulanowicz RE (eds) Aquatic food webs: an ecosystem approach. Oxford University Press, Oxford, p 25-40

De Vlas J (1979) Secondary production by tail regeneration in a tidal flat population of lugworms (Arenicola marina), cropped by flatfish. Neth J Sea Res 13:362-393

Duffy JE, Stachowicz JJ (2006) Why biodiversity is important to oceanography: potential roles of genetic, species, and trophic diversity in pelagic ecosystem processes. Mar Ecol Prog Ser 311:179-189

Ehlert W (1964) Zur Ökologie und Biologie einiger Limikolenarten. J Ornithol 105:1-53

Fast T, Müller A, Wilhelm A (1999) The Sylt-Rømø Bight ecosystem model (SRB model): an introduction. GKSS 99/E/28. GKSS Forschungszentrum, Geesthacht

Fath BD, Patten BC (1999) Review of the foundations of network environ analysis. Ecosystems 2:167-179

Fauchald K, Jumars PA (1979) The diet of worms: a study of polychaete feeding guilds. Oceanogr Mar Biol Annu Rev $17: 103-284$

Fenchel T, Koefoed LH (1976) Evidence for exploitative interspecific competition in mud snails (Hydrobiidae). Oikos $27: 367-376$

Field JG, Moloney CL, Attwood CG (1989) Network analysis of simulated succession after an upwelling event. In: Wulff F, Field JG, Mann KH (eds) Network analysis in marine ecology: an assessment, Coast Estuar Stud 32. SpringerVerlag, Berlin

Finn JT (1976) Measures of ecosystem structure and function derived from the analysis of flows. J Theor Biol 56: 363-380

Franke HD, Buchholz F, Wiltshire KH (2004) Ecological long term research at Helgoland (German Bight, North Sea): retrospect and prospect-an introduction. Helgol Mar Res 58:223-229

Gaedke U, Straile D (1994) Seasonal changes of trophic transfer efficiencies in a plankton food web derived from biomass size distributions and network analysis. Ecol Model 75/76:435-445

Gätje C, Reise K (eds) (1998) The Wadden Sea ecosystem: exchange, transport, and transformation processes. Springer, Berlin 
Heip C, Herman R, Vincx M (1984) Variability and productivity of meiobenthos in the Southern Bight of the North Sea. Rapp Pv Réun Cons Int Explor Mer 183:51-56

Heymans JJ, McLachlan A (1996) Carbon budget and network analysis of a high energy beach/surf zone ecosystem. Estuar Coast Shelf Sci 43:485-505

Hickel W (1984) Seston in the Wadden Sea (German Bight, North Sea). Neth Inst Sea Res Publ Ser 10:113-131

Ieno EN, Solan M, Batty P, Pierce GJ (2006) How biodiversity affects ecosystem functioning: roles of infaunal species richness, identity and density in the marine benthos. Mar Ecol Prog Ser 311:263-271

Jacobsen VH (1967) The feeding of the lugworm Arenicola marina (L.). Quantitative studies. Ophelia 4:91-109

Jensen KT, Siegismund HR (1980) The importance of diatoms and bacteria in the diet of Hydrobia-species. Ophelia (Suppl) 1:193-199

Kirchman DL, Newell SY, Hodson RE (1986) Incorporation versus biosynthesis of leucine: implications for measuring rates of protein biosynthesis and biomass production by bacteria in marine systems. Mar Ecol Prog Ser 32: $47-59$

Menge BA (1995) Indirect effects in marine rocky intertidal interaction webs: patterns and importance. Ecol Monogr 64:21-74

Monaco ME, Ulanowicz RE (1997) Comparative ecosystem trophic structure of three U.S. mid-Atlantic estuaries. Mar Ecol Prog Ser 161:239-254

Morris JT, Christian RR, Ulanowitz RE (2005) Analysis of size and complexity of randomly constructed food webs by information theoretic metrics. In: Belgrano A, Scharler UM, Dunne J, Ulanowicz RE (eds) Aquatic food webs: an ecosystem approach. Oxford University Press, Oxford, p 73-85

Nehls G, Hertzler I, Scheiffarth G (1997) Stable mussel Mytilus edulis beds in the Wadden Sea - They are just for birds. Helgol Wiss Meeresunters 51:361-372

NSF (1999) Decision-making and valuation for environmental policy. NSF Bulletin 99-14, National Science Foundation, Ballston, VI

Patricio J, Ulanowicz R, Pardal MA, Marques JC (2004) Ascendency as an ecological indicator: a case study of estuarine pulse eutrophication. Estuar Coast Shelf Sci 60: 23-35

Patten BC (1978) Systems approach to the concept of environment. Ohio J Sci 78:206-222

Patten BC (1985) Energy cycling in ecosystems. Ecol Model 28:1-71

Pihl L (1985) Food selection and consumption of mobile epibenthic fauna in shallow marine areas. Mar Ecol Prog Ser 22:169-179

Pihl L, Rosenberg R (1984) Food selection and consumption of the shrimp Crangon crangon in some shallow marine areas in western Sweden. Mar Ecol Prog Ser 15: 159-168

Polte P, Schanz A, Asmus H (2005) The contribution of seagrass beds (Zostera noltii) to the function of tidal flats as a juvenile habitat for dominant epibenthos in the Wadden Sea. Mar Biol 147:813-822

Editorial responsibility: Otto Kinne (Editor-in-Chief), Oldendorf/Luhe, Germany
Rick HJ, Rick S, Tillmann U, Brockmann U, Gartner U, Durselen C, Sündermann J (2006) Primary productivity in the German Bight (1994-1996). Estuar Coasts 29:4-23

Rusch A, Forster S, Huettel M (2001) Bacteria, diatoms and detritus in an intertidal sandflat subject to adjective transport across the water-sediment interface. Biogeochem 55: $1-27$

Rutledge RW, Bacore BL, Mulholland RJ (1976) Ecological stability: an information theory standpoint. J Theor Biol 57:355-371

Scharler UM, Baird D (2005) A comparison of selected ecosystem attributes of three South African estuaries with different freshwater inflow regimes, using network analysis. J Mar Syst 56:283-308

Scheiffarth G (2001) The diet of bar-tailed godwits Limosa lapponica in the Wadden Sea: combining visual observations and faeces analysis. Ardea 89:481-494

Scheiffarth G, Nehls G (1997) Consumption of benthic fauna by carnivorous birds in the Wadden Sea. Helgol Wiss Meeresunters 51:373-387

Scheiffarth G, Wahls S, Ketzenberg C, Exo KM (2002) Spring migration strategies of two populations of bar-tailed godwits Limosa lapponica in the Wadden Sea: time minimizers or energy minimizers? Oikos 96:346-354

Sieburth JM, Jensen A (1969) Studies on algal substances in the sea. II. The formation of Gelbstoff (humic material) by exudates of phaeophyta. J Exp Mar Biol Ecol 3:257-289

Thomas CR, Christian RR (2001) Comparison of nitrogen cycling in salt marsh zones related to sea-level rise. Mar Ecol Prog Ser 221:1-16

Ulanowicz RE (1986) Growth and development: ecosystem phenomenology. Springer-Verlag, New York

Ulanowicz RE (2003) Some steps toward a central theory of ecosystem dynamics. Comput Biol Chem 27:532-530

Ulanowicz RE (2004) Quantitative methods for ecological network analysis. Comput Biol Chem 28:312-339

Ulanowicz RE, Abarca-Arenas LG (1997) An informational synthesis of ecosystem structure and function. Ecol Model 95:1-10

Ulanowicz RE, Kay JJ (1991) A package for the analysis of ecosystem flow networks. Environ Software 6:131-142

Ulanowicz RE, Kemp WM (1979) Towards canonical trophic aggregations. Am Nat 114:871-883

Ulanowicz RE, Norden JS (1990) Symmetrical overhead in flow networks. Int J Systems Sci 21:429-437

Valiela I (1995) Marine ecological processes. Springer-Verlag, New York

Vegter F, De Visscher PR (1984) Extracellular release by phytoplankton during photosynthesis in Lake Greveling (SW Netherlands). Neth J Sea Res 18:260-270

Wiltshire KH, Manly BFJ (2004) The warming trend at Helgoland Roads, North Sea: phytoplankton response. Helgol Mar Res 58:269- 273

Wulff F, Field JG, Mann KH (eds) (1989) Network analysis in marine ecology: methods and applications. Coast Estuar Stud 32. Springer-Verlag, Heidelberg

Zwarts L, Blomert AM (1992) Why knot Calidris canutus take medium-sized Macoma balthica when six prey species are available. Mar Ecol Prog Ser 83:113-128

Submitted: July 20, 2006; Accepted: July 3, 2007

Proofs received from author(s): November 12, 2007 